\title{
Autosomal recessive spastic paraplegia type 62
}

INSERM

\section{Source}

INSERM. (1999). Orphanet: an online rare disease and orphan drug data base. Autosomal recessive spastic paraplegia type 62. ORPHA:401785

Autosomal recessive spastic paraplegia type 62 is a pure or complex form of hereditary spastic paraplegia characterized by an onset in the first decade of life of spastic paraperesis (more prominent in lower than upper extremities) and unsteady gait, as well as increased deep tendon reflexes, amyotrophy, cerebellar ataxia, and flexion contractures of the knees, in some. 